This item was submitted to Loughborough's Research Repository by the author.

Items in Figshare are protected by copyright, with all rights reserved, unless otherwise indicated.

\title{
Book Review: TV Socialism by Aniko Imre
}

PLEASE CITE THE PUBLISHED VERSION

https://doi.org/10.1177/1077699018758730

PUBLISHER

SAGE @ AEJMC

VERSION

AM (Accepted Manuscript)

PUBLISHER STATEMENT

This work is made available according to the conditions of the Creative Commons Attribution-NonCommercialNoDerivatives 4.0 International (CC BY-NC-ND 4.0) licence. Full details of this licence are available at: https://creativecommons.org/licenses/by-nc-nd/4.0/

\section{LICENCE}

CC BY-NC-ND 4.0

\section{REPOSITORY RECORD}

Mihelj, Sabina. 2019. "Book Review: TV Socialism by Aniko Imre”. figshare. https://hdl.handle.net/2134/32965. 
TV Socialism. Anikó Imre. Durham, NC: Duke University Press, 2016. 328 pp. \$29.95 hbk. \$94.95 pbk.

Reviewed by: Sabina Mihelj, Loughborough University, UK

While the historical trajectories of television in liberal democracies of Western Europe and Northern America have generated sustained and substantial scholarly attention, the history of television in countries under communist rule has long remained on the margins of scholarly interest. In recent years, however, socialist television started emerging as an attractive object of investigation, one that has potential to offer important and often surprising insights into the nature of mass communication under authoritarian rule. Pioneering work on the subject initially came from historians, typically in the form of monographs focused on a single country, such as Paulina Bren's (2010) pioneering study of Czechoslovak television after the 1968 Prague Spring, Christine Evans' (2016) history of Soviet Central Television, or Heather Gumbert's (2015) study of East German television. More recently, media and communication scholars started discovering socialist television as well, often using it as a means of revisiting established concepts and theoretical frameworks in the field. Aniko Imre's TV Socialism is the first English language monograph emerging from this new body of research, as well as the first to move beyond the single-country framework. Although the majority of original archival and interview data used in the book comes from Hungary, Imre does a fine job at situating this material in the wider context of socialist Eastern Europe, drawing on a vast range of secondary sources.

Apart from representing a major intervention in the field of socialist television studies, TV Socialism also engages the wider audience of television studies experts and media and communication scholars, and makes a compelling case for an alternative history of Cold War television. Imre's main line of argumentation revolves around "moments of defamiliarization and surprise" - that is, aspects of socialist television that do not conform to prevailing Western stereotypes of media and culture under communist rule. As Imre shows, socialist television was far from a straightforward means of propaganda; even though communist authorities were eager to exploit its persuasive powers, they also looked down on the medium and perceived it as inferior to established cultural forms such as literature or film. This low cultural status meant that television - and television entertainment, in particular - could often escape censorial scrutiny. Other "moments of surprise" include similarities with Western television, a wide range of innovative, hybrid programming mixing the conventions of educational and entertainment genres, and the prominence of transnational exchanges and influences. For instance, readers may be surprised to find that socialist television schedules abounded with game, quiz and variety shows which in many ways resembled their Western siblings and often foregrounded values and practices that seemed at odds with the collectivist ethos of the communist project, including individual success and consumerism. Yet at the same time, these programmes also blended of entertainment with educational goals, and were guided by a competitive impetus that was central to Cold War politics and culture.

Rather than following a chronological narrative or adopting a comparative framework, Imre organised her analysis according to what she calls a 'generic logic'. Each of the four parts of the book examines one key generic category of state socialist programming: reality-based educational genres, historical and adventure series, dramatic series, and comedic programmes. The choice of genre as a key organisational tool is in line with the author's academic trajectory, which is rooted in traditions of film and cultural studies - Imre is currently Professor and Chair of the Division of Cinema \& Media Studies in the School of Cinematic Arts at the University of Southern California, and is known for her prior work on East European cinema, post-socialist media culture, and feminist media studies. The 
key advantage of the 'generic logic' is its ability to accommodate both diachronic and synchronic modes of analysis: for each of the four key generic categories, Imre offers a broad outline of regional trends, illustrates them with case studies from different countries, and discusses both socialist and post-socialist developments. As such, the generic approach offers an effective analytical template for transnational television studies, and will certainly be taken up by other authors working in the field. That said, the generic lens also, perhaps inevitably, focuses analytical attention primarily on media texts rather than on institutional and policy frameworks or processes of production and reception, and tends to privilege individual programmes rather than capturing the logic of flow and scheduling through which these programmes reach audiences. Imre is of course well aware of the need for a more all-encompassing approach, and her investigation regularly ventures into aspects of the industrial and production context, as well as critical and audience reception. Nonetheless, the main focus of analysis, and indeed the main strength of TV Socialism, lies in the analysis of programmes themselves; it is here that Imre develops some of her most original and intriguing arguments, which will no doubt continue to shape debates on socialist television and its place in global television history for some time to come.

\section{References:}

Bren, Paulina. 2010. The Greengrocer and His TV: The Culture of Communism after the 1968 Prague Spring. Ithaca: Cornell University Press.

Evans, Christine. 2016. Between Truth and Time: A History of Soviet Central Television. New Haven: Yale University Press.

Gumbert, Heather. 2014. Envisioning Socialism: Television and the Cold War in the German Democratic Republic. Ann Arbor: University of Michigan Press. 